\title{
Islamic and Western political thought: does History have any Lessons?
}

\author{
Anthony Black \\ University of Dundee, United Kingdom
}

Today the values of liberal democracy have spread over almost the whole globe. Many people want them even when they do not have them. These values come from Western political thought.

One serious competitor to Western values is Islamism: the attempt to model society and the state according to the alleged pattern of Islam in the 7th century. The other type of Muslim political thought today is Modernism (or Reformism): that is, the attempt to combine Islamic values with liberal democracy.

This article will examine this present situation in the light of the history of Islamic political thought, and compare this with the history of Western political thought. Comparisons between different traditions can sometimes help to throw light on both of them, by showing where they resembled or differed from each other. It may also suggest the role of the different influences to which each was exposed, for example Rome in the case of the West, and Iran in the case of Islam. Max Weber believed that comparative study might explain why modern capitalism emerged where it did.

It is also worth bearing in mind that Byzantium or East Rome inherited a culture similar to the West but developed it in a way that was different from either the West or Islam. This surely demonstrates that Christian ideas themselves do not explain the phenomenon of Western political thought.

Islam arose in the tribal society of Arabia in the early to middle years of the 7th century. The Prophet Muhammad and his followers preached not only about God and morality, they also laid down the foundations of what would become-- and was surely meant to be-- a state, and a system of civil and criminal law. There was no distinction between religion and the state. This was very different from Jesus and his followers, who had accepted the Roman state and its law. 
The first Muslims regarded Muhammad and those appointed to succeed him (the Imams, caliphs or deputies of the Prophet) as their leaders in all aspects of life: social, legal and political as well as spiritual and moral. The new religious community was to be ruled by a single commander. He was chosen, according to the Sunnis, by consensus; acc ording to the Shi'a by designation by Muhammad or the previous caliph. Rules for taxation, civil disputes, punishment of crime were all deduced from texts revealed to Muhammad (the Quran and Hadith). $\{1\}$ I would suggest that the most important difference between Christian and Islamic political thought was-- and still is-- that Christianity, unlike Islam, began as a non-political religion.

However, in practice, a distinction developed between the 'ulama', who taught religion and morals, and the sultans, who had military and political power. Religious authority and political power now belonged to different people. Sufism in particular discouraged participation in politics.

Western political thought began long before Islam in the ancient Greek city-states and in the Roman republic. The first Christians rejected all forms of violence and had as little as possible to do with politics. But, when Christianity became the official religion of the Roman empire in the 4th century, Christians began to see the state and the church as two aspects of a single Christian society, and the emperor a religious leader. This became the official doctrine of the Byzantine empire, and remained the official doctrine of the Russian empire until 1917. $\{2\}$

Both Islamic ulama' and Christian priests supported their respective monarchs in return for his support of religious institutions and the true faith. Thus in practice Christian and Islamic states came to resemble one another-- for a while.

There were three distinct schools of political thought in classical Islam: religious jurisprudence (fiqh), philosophy and handbooks for rulers. Religious jurisprudence was mainly about civil society: marriage, contracts, commerce, inheritance and so on. It was based on the Quran and the Hadith as interpreted by the consensus (ijma') of the early jurists. $\{3\}$

The Muslim philosophers $\{4\}$ equated the Caliphate with Plato's ideal state. They interpreted the Quran by human reason rather than Hadith. For example, the state should redistribute wealth to the poor but it must punish laziness. Ibn Khaldun used Aristotle's empirical and rational approach to explain why the caliphate had declined, as all human regimes must. He thus invented the discipline of sociology; his work was not superceded until the 19th century. 
Advices to Kings $\{5\}$ similarly used the political ideas of pre-Islamic Iran to specify what the caliphate or state should do, and to suggest how it could do it. Beginning with Ibn Muqaffa' (who transmitted ancient Iranian statecraft and literature to the Muslim world), they applied statecraft-- or as we might say business management-- to the government of the Muslim community. All kinds of force and deceit are permissible, provided the aim is social stability and the expansion of Islam. Up to the 11th century, then, there was more political thought in the Muslim-ruled world (dar al-Islam) than there was in Europe.

Handbooks for rulers continued to be produced till the nineteenth century. Philosophy, however, fell into disfavour because, according to the orthodox 'ulama', it replaced revelation with reason. The orthodox 'ulama' rejected all argument that was not based on the Quran and hadith, as interpreted by them.They quickly gained the support of mass public opinion. This was a form of fundamentalism not unlike that of today. Any new ideas were forbidden, their authors punished. This put a stop to rational and empirical thought in the dar alIslam. The philosopher-theologian Al-Ghazali -- possibly the greatest intellectual figure in East or West-- delivered the final blow by arguing the philosophy could not prove its own premises-- which is true ('The Incoherence of the Philosophers'). $\{6\}$ This remained the intellectual situation in the Muslim-ruled world until the middle of the 19th century. The works of Muslim philosophers were read by Europeans and virtually forgotten among Muslims. This was a catastrophy.

Furthermore, from the 11th century onwards, leading orthodox juristic thinkers in the Muslim-ruled world, such as al-Mawardi and Ibn Taymiyya, began to reaffirm the original Islamic principle of the unity of religious and political power under the caliph or his delegates, the sultans. Sultans must apply the Shari'a as interpreted by the 'ulama'. Ibn Taymiyya emphasised the duty of jihad, especially defensive war against the Mongols. $\{7\}$

But at the same time significant changes were taking place in Western Christianity as well as in Islam. Christian society was seen as a single whole with two powers-priests and kings. In what is sometimes called the first European revolution, the Reform Papacy of the eleventh century began to teach that kings are subordinate to priests, at least in religious matters, which they defined very widely. $\{8\}$ The same popes preached the First Crusade in response to the Turkish invasion of Anatolia. Were church leaders perhaps trying to set up a unified religious polity as they conceived Islam to be? 
Christian Kings and many philosophers reacted against this by invoking the statement of Jesus that the affairs of God and of Caesar (the state) are completely different. They argued that the state and its constitution could be deduced from human reason. It was now the Christans' turn to revive the philosophy of ancient Greece, especially Aristotle. The argued that kings derive their authority not from God through the church, but from God through nature. The state was the product of human nature. Some took this to mean that kings derive their authority from the people ( Marsilius of Padua). $\{9\}$ It is important to note here that Muslim philosophers had not taken this step, I am not quite sure why. Political questions, according to this new European view, should be decided by reason and experience.

Hence, in the period 1100-1400, there was a second reversal in the view of the relationship between religion and the state in Islam and the West respectively. Now each reverted to something closer to its original position: namely, bringing together religion and political authority in the dar al-Islam, and separating them in the Christian West.

Thus the Renaissance came early in Islamic intellectual history, but it was also fairly quickly snuffed out. In Europe, secular philosophy took permanent root: ideas, ways of thinking and feeling, flowed into Europe from Greece and Rome from 12th till 19th century. And it was the Roman philosophy of Stoicism which, in the 18th century, gave rise to the modern idea of human rights. $\{10\}$ It was, however, a slow and long process, and there were times when it might have been reversed.

The European Reformation, when Protestants rejected the authority of the Roman Catholic church, unintentionally gave rise to a yet further secularison of political thought. The domestic and international wars between Christians (and only present-day Iraq reminds us of how vicious these coould be) made people base political authority on something other than religion. The idea of a secular state developed in Europe in the 17th century. $\{11\}$

It seems to me that these very different histories lie behind the different political attitudes of the West and of many Muslim-majority countries today.

However, in the later 19th century, a new phase opened in Muslim political thought.

European powers now controlled much of the dar al-Islam economically and even politically. This inspired some Muslim theorists to attempt something new. They saw that the military and economic success of the West owed much to its political system. They admired representative government and the rule of law. This led them to revisit the Muslim past and ask what had gone wrong. They concluded that the 
decline of the Muslim world was due to tyranny and corrupt government. This is what had led to intellectual stagnation. The West, on the other hand, had derived its superior political ideas from early Islam.

These Muslim thinkers saw their task as to revive the power of original Islam in today's world. This meant adopting the superior political systems of the West. This produced Islamic Modernism. \{12\} Modernists believe that democracy and the rule of law are expressions of Islamic values. Democracy is the modern equivalent of consensus (ijma'). Baya (the oath taken to a new caliph) implies a contract between rulers and ruled. They think that parts of the Shari'a should be brought up to date, and that modern Western values, such as the equality of women, correspond to the spirit of the Quran.

But events in the 20th century led other Muslims to reject Western ideas altogether, and to argue that you can derive a complete political system from a new interpretation of original Islam. This is 'Islamism'. It might include some Western values, such as democracy, but it would exclude others, such as equal treatment of unbelievers. Islamists tend to believe in the emergence of a charismatic leader, possibly without the need for an election. $\{13\}$

There are many varieties of Modernism and Islamism, and sometimes they merge. For example, the so-called 'Islamist' party ruling Turkey today includes much that is Modernist. It is in this discourse that the fate of the jasmine revolution will be determined, in Tunisia, Egypt and elsewhere.

The reinterpretation of the Quran and of early Islamic practice undertaken by the Modernists has led to the almost universal acceptance of democracy by both Modernists and Islamists.

The outstanding problem concerns human rights, especially religious liberty. The West, and also the UN, uphold the view that all human beings, simply in virtue of their humanity, have the same civil and political rights, regardless of, among other things, their religion or lack of it. Muslims living in the West seem to agree. $\{14\}$ But a great many Muslims living in Muslim-majority states do not adhere to this, at least practice. Think of Saudi Arabia. And what is more, it seems to me that the great majority of Muslim thinkers refuse explicitly to confront this.

However, there are two modern Muslim thinkers who have attempted a fundamental reinterpretation of the Quran and Muslim tradition in a way which might overcome this problem: 'Abd al-Raziq and Abdullahi Ahmed An-Na'im. They have, in different ways, asserted a fundamental distinction between religion and politics. 'Abd al-Raziq argued that the Prophet set up the caliphate-- that is, 
founded a state-- and engaged in holy war only because of political necessity. Muslims today are not obliged to follow norms established for tribal Arabia. They are free to adopt whatever form of state and constitution seems best, such as liberal democracy. They are free to use their own reason and experience in political matters. $\{15\}$

It is worth recalling here that Christians have over the past two centuries applied historical and literary criticism to their Bible. They have recognised that it was written at a specific time for a specific audience, and therefore not everything in it can or should be taken literally today. For example, the early Christians discouraged marriage and accepted slavery. They taught neither liberalism nor democracy. Yet nowadays, Christians celebrate marriage, outlaw slavery, and many regard liberal democracy as a logical conclusion from Christian principles.

An-Na'im has gone further. Following his religious teacher, Taha, he distinguishes, within the Quran itself, between those parts which derive from Muhammad's original revelation at Mecca, and those which were written after the flight to Medina and during the war with the Quraysh to regain Mecca. The 'Meccan' texts contain general ethical and religious teaching, which is indeed obligatory and unchanging. The 'Medinan' texts, on the other hand, contain more specific teachings in response to an emergency situation due to persecution by his opponents. Taha and An-Na'im put in this category holy war and the command to kill unbelievers, as well as many of the specific provisions of the traditional Shari'a on punishments for crimes, marriage, the status of women and so on. These were concessions to the time and culture in which Muhammad lived. Therefore, they can be abrogated. An-Na'im quite explicitly states that all citizens should be treated equally regardless of their religion. $\{16\}$

Such an approach takes us back to the classical Muslim philosophers. It also seems to me to be reflected in the practice of the jasmine revolution. However, it is far from being endorsed as yet by other Muslim scholars. 'Abd al-Raziq's writings were condemned and he was thrown out of his University in Cairo. An-Na'im lives in the USA.

Putting this in more general terms, one can ask of any belief system how one should distinguish between ethical principles and purely pragmatic considerations (between ends and means, if you like). Furthermore, Western, and indeed in some cases Christian, thinkers have developed their own ethical principles (not just the means of applying them) in the light of ideas and arguments which were of nonreligious origin, including those drawn from ancent Greece and Rome. Some of the earlier Muslim philosophers also did this. But recently Christians and Westerners 
have been far more willing to learn from non-revealed sources, and to adapt to circumstances. This latter can of course lead to moral lapses, as for example in early industrial Britain. It is always a matter of moral judgment.

In conclusion, the history of both Islamic and Western political thought demonstrates that believers in a revealed religion can interpret their revealed texts in significantly different ways. We have seen some Christians bringing religion and the state together, and some Muslims separating them. The idea that there is one and only one fixed meaning of a revealed text, at least so far as practical matters such as politics are concerned, is mistaken.

On the other hand, in the cases we have looked at, divergence from the original meaning did not last. That is to say, when pressed, Muslims reasserted the unity of religion and politics, Christians reasserted their separation. It seems to me, therefore, that the original texts do exert a lot of power over believers, at least in the long term. This is an essentialist view of religious faith which is contrary to the way many scholars think nowadays. The original texts do, I think, exercise power over what people think, and most importantly over what is is permissible to say in public. They can therefore have significant influence on actual policy.

It is true that in the world today states inhabited by mainly Muslims and states inhabited by mainly Christians or secular persons conduct business as usual without much day-to-day attention to their different religious views. Muslimmajority states, for example, participate in global economic and peace-keeping affairs in the same eway that non-Muslim states do. They conduct their relations with other states according to their economic and territorial interests and their view of a desirable international order. But the notion of the "umma (the worldwide community consisting of Muslims only) remains at the back of theior minds, and in certain crises may influence policy. Just think of Israel and Palestine. Religious leaders or opposition groups can invoke these ideas in times of crisis. The same applies to Christianity in the USA.

All this may serve to remind us that it is very important how a human being thinks he or she knows what is true and right: that is, to what extent these are known from revelation, and to what extent they are known by human thought and experience.

\section{References and Notes:}

1. Patricia Crone, Medieval Islamic Political Thought (Edinburgh University Press, 2004).

2. Antony Black, The West and Islam: Religion and Political Thought in World History (Oxford University Press, 2008). 
3. Wael B. Hallaq, The Origins and Evolution of Islamic Law (Cambridge University Press, 2005).

4. Encyclopaedia of Islam, 2nd edn, eds H.A.R.Gibb and others (Brill, 1960-96)=EI, on Falsafa.

5. EI on Nahisat al-Muluk

6. Crone, Medieval, 137-47

7. EI on Ibn Taymiyya

8. R.I. Moore, The First European Revolution, c.970-1215 (Blackwell, 2000)

9. Antony Black, Political Thought in Europe, 1250-1450 (Cambridge University Press, 1992)

10. But see Brian Tierney, The Idea of Natural Rights: Studies on Natural Rights, Natural Law and Church Law 1150-1625 (Scholars Press, 1997)

11. But see Quentin Skinner, The Foundations of Modern Political Thought (Cambridge University Press, 1978)

12. Charles Kurzman (ed.), Liberal Islam: a Sourcebook (Oxford University Press, 1998); Niyazi Berkes, The Development of Secularism in Turkey (McGill University Press, 1964)

13. Youssef M. Choueiri, Islamic Fundamentalism, rev. edn (Pinter, 1997)

14. Mehran Kamrava (ed.), The New Voices of Islam: Reforming Politics and Modernity: a Reader (Tauris, 2006), 18

15. Erwin I.J. Rosenthal, Islam in the Modern Nation State (Cambridge University Press, 1965), 85-101

16. Abdullahi Ahmed An-Na'im, Islam and the Secular State (Harvard University Press, 2008)

\title{
SUMMARY
}

\section{Islamic and Western political thought: does History have any Lessons?}

\author{
Anthony Black \\ University of Dundee, United Kingdom
}

Revealed religions may be interpreted in different ways. But their original texts influence people over the ages. The West was also greatly influenced by ancient Greece and Rome. Today, Muslims have mostly accepted democracy but not yet equal rights for unbelievers. This remains an area of dispute. 